\title{
Stannate-Based Ceramic Oxide as Anode Materials for Oxide-Ion Conducting Low-Temperature Solid Oxide Fuel Cells
}

\author{
A. Mohammed Hussain, Ke-Ji Pan, Ian A. Robinson, Thomas Hays, ${ }^{*}$ \\ and Eric D. Wachsman ${ }^{* *, z}$ \\ University of Maryland Energy Research Center, University of Maryland, College Park, Maryland 20742, USA
}

\begin{abstract}
Lanthanum-doped barium stannate, $\mathrm{Ba}_{0.98} \mathrm{La}_{0.02} \mathrm{SnO}_{3}$ (LBS) ceramic oxide was developed as an alternative redox stable anode material for oxide-ion conducting, low-temperature solid oxide fuel cells $\left(350-650^{\circ} \mathrm{C}\right)$. LBS with $\mathrm{ZnO}$ as a sintering aid exhibited a high electronic conductivity of $216 \mathrm{~S} / \mathrm{cm}$ at $650^{\circ} \mathrm{C}$ under reducing gas conditions. A flexural strength of $\sim 66 \mathrm{MPa}$ at $550^{\circ} \mathrm{C}$ was obtained for $\mathrm{ZnO}$-doped LBS; further investigation revealed that it can withstand 10 reduction-oxidation and thermal cycles. The performance of ZnO-doped LBS as an anode was determined with a GDC based electrolyte-supported SOFC. The catalytic activity for hydrogen oxidation and oxide conductivity was introduced by infiltration of Ni-GDC precursor. The maximum power densities of $0.28 \mathrm{~W} / \mathrm{cm}^{2}\left(\right.$ at $\left.0.6 \mathrm{~A} / \mathrm{cm}^{2}\right)$ and $0.17 \mathrm{~W} / \mathrm{cm}^{2}\left(\right.$ at $0.36 \mathrm{~A} / \mathrm{cm}^{2}$ ) was achieved at 650 and $600^{\circ} \mathrm{C}$, respectively, in humidified hydrogen as fuel for $2 \mathrm{wt} \% \mathrm{ZnO}$-doped LBS.
\end{abstract}

(C) 2016 The Electrochemical Society. [DOI: 10.1149/2.0691610jes] All rights reserved.

Manuscript submitted May 24, 2016; revised manuscript received August 9, 2016. Published August 20, 2016. This was Paper 1412

from the San Diego, California, Meeting of the Society, May 29-June 2, 2016.

Solid oxide fuel cells (SOFCs) are highly efficient, electrochemical energy conversion devices that utilize a range of fuels such as hydrogen, natural gas, gasoline, diesel or biofuel with air as oxidant. ${ }^{1}$ Development of efficient SOFCs at a lower cost is essential for commercialization. ${ }^{2}$ Problems associated with conventional high temperature operating SOFCs $\left(\geq 800^{\circ} \mathrm{C}\right)$, such as degradation of stack materials, slow startup time and thermal cycling instability can be improved by lowering the operating temperature. As such, extensive efforts are underway to develop low operating temperature solid oxide fuel cells (LT-SOFCs, 350-650 ${ }^{\circ}$ C). ${ }^{3,4}$ LT-SOFCs can satisfy the power requirement in the ranges between $0.01-100 \mathrm{~kW}$ for a variety of applications such as residential (e.g., powering households), transportation (e.g., range extender for plug-in-vehicles) and military and portable needs (e.g., remote access, charger for laptops/cell phones). ${ }^{3}$ Moreover, LT-SOFCs enable the use of nanostructured electrodes to obtain high performance without compromising long-term stability. In addition, lower temperature enables the use of low-cost compressive gasket seals and inexpensive materials e.g., steel interconnects., ${ }^{4,5}$

Ni-GDC based metal-ceramic composite (cermet) is a commonly used anode for LT-SOFCs and a high performance of $2 \mathrm{~W} / \mathrm{cm}^{2}$ at $650^{\circ} \mathrm{C}$ in $\mathrm{H}_{2}$ was achieved using Ni-GDC cermet anode. ${ }^{3}$ However, they impose challenges for fuel cell developers. For example, $\mathrm{Ni} / \mathrm{NiO}$ volumetric changes upon reduction-oxidation cycles are irreversible. ${ }^{6}$ $\mathrm{Ni-GDC}$ based cermet is prone to carbon deposition and sulfur poisoning in the hydrocarbon-based fuels, albeit with greater tolerance than Ni-YSZ anodes. ${ }^{7}$ Carbon deposition can be prevented by internal steam reforming of $\mathrm{CH}_{4}$; however considerable dilution (steam content $\geq 50 \%$ ) of fuel is needed, which affects the cell voltage. ${ }^{4}$ Further, Ni-GDC based cermet anodes are weak under the anode operating conditions due to the reduction of $\mathrm{NiO}\left(\mathrm{Ni}^{2+/ 0}\right)$ and ceria $\left(\mathrm{Ce}^{4+/ 3+}\right){ }^{6}$ Porosity induced by pore-formers further weakens the cermet anode support. Moreover, coarsening of Ni under long-time operation impacts the reliability of LT-SOFC made using Ni-GDC cermet as an anode.

In order to develop reliable, cost effective LT-SOFC technology, identification of alternative anode materials is critical. Alternative anode materials should meet certain characteristics to function as an efficient SOFC anode. The major requirements include high electrical conductivity, high catalytic activity for oxidation of fuels, $\mathrm{O}^{2-}$ conductivity to enlarge the triple phase boundaries (TPB), high mechanical strength, sufficient porosity, thermal compatibility with electrolyte and exceptional reduction-oxidation (redox), thermal, and chemical stability. Perovskite-type oxides exhibit characteristics that

\footnotetext{
*Electrochemical Society Student Member

**Electrochemical Society Fellow.

${ }^{\text {z} E-m a i l: ~ e w a c h @ u m d . e d u ~}$
}

are required for an efficient fuel electrode for LT-SOFCs, broadly classified by two types of ceramic oxides. The first one is mixed oxide-ion/electronic conductors (MIEC) such as chromates (e.g., $\left.\mathrm{La}_{0.75} \mathrm{Sr}_{0.25} \mathrm{Cr}_{0.5} \mathrm{Mn}_{0.5} \mathrm{O}_{3}\right)^{8-10}$ or molybdates (e.g., $\mathrm{Sr}_{2} \mathrm{MgMoO}_{6}$ ). ${ }^{11,12}$ MIEC type perovskite oxides are usually redox stable and are catalytically active at high temperatures. The second one is mostly electronic conducting (EC) ceramic oxides such as titanates (e.g., $\left.\mathrm{SrTi}_{0.75} \mathrm{Nb}_{0.25} \mathrm{O}_{3}\right) .{ }^{13-15}$ These materials possess excellent redox stability, however, they lack catalytic activity and oxide conductivity, which are usually incorporated by infiltration of catalysts. Nevertheless, both MIEC and EC, ceramic oxides require high temperature $\left(>900^{\circ} \mathrm{C}\right)$ pre-reduction to achieve high electronic conductivity.

$\mathrm{BaSnO}_{3}$ substituted on the $\mathrm{Ba}$ and/or Sn-site with trivalent cations (such as $\mathrm{Fe}, \mathrm{Sc}, \mathrm{In}, \mathrm{Y}, \mathrm{Gd}, \mathrm{Sm}, \mathrm{Nd}$ and La) are mixed proton and electronic conductors. ${ }^{16,17}$ These materials have been extensively investigated for their application as photocatalyst, ${ }^{18}$ thermoelectric, ${ }^{19}$

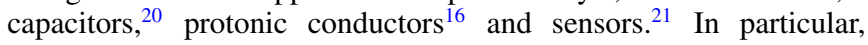
$\mathrm{La}_{2} \mathrm{O}_{3}$-doped $\mathrm{BaSnO}_{3}$ is an n-type semiconductor with interesting electrical properties. ${ }^{22}$ Under low $\mathrm{pO}_{2}$ conditions, the electrical conductivity of La-doped $\mathrm{BaSnO}_{3}$ is mainly achieved by substitution of $\mathrm{Ba}^{2+}$ by $\mathrm{La}^{3+}$, which leads to a reduction of $\mathrm{Sn}^{4+}$ to $\mathrm{Sn}^{2+}$ and electron donation. The ionic radius of $\mathrm{La}^{3+}(1.36 \AA)$ is smaller than $\mathrm{Ba}^{2+}(1.61 \AA)$ in 12 -fold coordination, as such lattice constant slightly increases with $2 \%$ La-doped $\mathrm{BaSnO}_{3}$ when compared to undoped $\mathrm{BaSnO}_{3} \cdot{ }^{23,24}$ Hadjarab et al. proposed that the partial reduction of $\mathrm{Sn}^{4+}(0.69 \AA)$ to $\mathrm{Sn}^{2+}(1.12 \AA)$ in the octahedral site induced by Ladoping could increase the lattice constant. ${ }^{25}$

Until now no studies have been reported on utilizing this material as anode for oxide-ion conducting SOFCs. In this work, we investigated the applicability of LBS as novel alternative anode material for oxide-ion conducting LT-SOFCs. The sinterability of the material was greatly improved by adding $\mathrm{ZnO}$ as a sintering aid. The material was characterized considering the LT-SOFC anode requirements, such as electrical conductivity, mechanical strength, redox, chemical and thermal stability at temperatures $\leq 650^{\circ} \mathrm{C}$. ZnO-doped LBS shows high electronic conductivity, excellent redox and thermal stability in LT-SOFC anode operating conditions. Compatibility of ZnO-doped LBS with GDC electrolyte was also investigated. GDCbased electrolyte-supported SOFCs were successfully fabricated and the electrochemical performance of $\mathrm{ZnO}$-doped LBS was evaluated.

\section{Experimental}

Sample preparation.-The solid-state synthesis was used to prepare LBS. Stoichiometric amounts of barium carbonate $\left(\mathrm{BaCO}_{3}\right.$, Alfa Aesar), tin oxide $\left(\mathrm{SnO}_{2}\right.$, Alfa Aesar), lanthanum oxide $\left(\mathrm{La}_{2} \mathrm{O}_{3}\right.$, Alfa Aesar) were ball-milled for $24 \mathrm{~h}$ in ethanol. Subsequently, ethanol was 
evaporated and the resulting oxides were heat-treated at $1300^{\circ} \mathrm{C}$ for 6 $\mathrm{h}$ to form the $\mathrm{Ba}_{0.98} \mathrm{La}_{0.02} \mathrm{SnO}_{3}$ cubic perovskite-type oxide.

Zinc oxide (ZnO, J.T. Baker) was used as a sintering aid for LBS in the weight percent of 1,2 and 3. The already prepared LBS powder was mixed with the three concentrations of $\mathrm{ZnO}$ for $12 \mathrm{~h}$ in ethanol separately. Ethanol was then dried and the resulted powder samples were collected and calcined at $1200^{\circ} \mathrm{C}$ for $6 \mathrm{~h}$.

Sample characterizations. - The crystal structure of the resulting ceramic oxide was determined using a Bruker D8 powder X-ray diffractometer with $\mathrm{Cu} \mathrm{K}$-alpha radiation. The XRD patterns were analyzed using TOPAS software to extract the lattice parameter. The LBS peaks were indexed for cubic symmetry having a space group $\mathrm{pm}$ $\overline{3} m$ using Le Bail fitting procedure. The relative crystallite sizes of the powders from XRD data were determined using the same procedure.

DC electrical conductivity measurements were performed on $\mathrm{ZnO}$ doped LBS (Zn-LBS) rectangular bars. The bar samples were prepared by ballmilling $\mathrm{Zn}$-LBS powder (3/4 ${ }^{\text {th }}$ of the $100 \mathrm{ml}$ bottle was filled with $\varnothing 10$ zirconia balls) over a period of $15 \mathrm{~h}$ in ethanol, followed by evaporation of ethanol and powder compaction. The compacted pellets were sintered at $1550^{\circ} \mathrm{C}$ for $6 \mathrm{~h}$ in air. The porosity of the sintered samples determined using Archimedes principle (buoyancy method) using Mettler Toledo's Density Kit. Samples with 0, 1, 2 and 3 wt\% Zn-LBS had a porosity of 50.4, 19.0, 9.1 and $6.7 \%$, respectively. Silver wires and silver paste was used as the I-V probe and current collector, respectively and attached to a Keithley 2400 source meter. The measurements were made using an in-house reactor capable of operating under controlled oxygen partial pressures. For electrical conductivity measurement, in the range of $350-650^{\circ} \mathrm{C}$, the samples were heated up in $\mathrm{N}_{2}$ and changed to $10 \% \mathrm{H}_{2} / 3 \% \mathrm{H}_{2} \mathrm{O} / 87 \% \mathrm{~N}_{2}$ gas conditions. This gas composition was used considering the safety issues of using pure/humidified $\mathrm{H}_{2}$ in our in-house reactor. The samples were allowed to stabilize in reducing gas conditions at $650^{\circ} \mathrm{C}$ over a period of $12 \mathrm{~h}$ and measurements were made at $50^{\circ} \mathrm{C}$ intervals. At each temperatures the samples was allowed to stabilize for 30 minutes.

The flexural strength of Zn-LBS was determined using a threepoint bend test. A Tinius Olsen H25K-T benchtop Universal Testing Machine (UTM) was used to determine the strength at room temperature, 400,550 and $650^{\circ} \mathrm{C}$ in air. The samples for mechanical testing were prepared by compaction of $\mathrm{Zn}$-LBS powder using a rectangular die. Each rectangular pellet was compacted separately to dimensions of length $2.5 \mathrm{~cm}$ and width $1 \mathrm{~cm}$ and sintered at $1550^{\circ} \mathrm{C}$ in air. Rectangular bars of the material were placed on support rods with a fixed spacing. A point load was then applied at a constant strain rate until failure. The maximum force experienced by the bar was recorded and the corresponding flexural stress calculated using Eq. 1.

$$
\text { Flexural strength, } \sigma=\frac{3 F L}{2 b d^{2}}
$$

Where, $\mathrm{F}$ is the applied force in Newtons. $\mathrm{L}, \mathrm{d}$, and $\mathrm{b}$ are length, thickness and width respectively. 5 samples were tested at each temperature to maintain accuracy in results.

For the preparation of electrolyte-supported cells, a $\mathrm{Gd}_{0.1} \mathrm{Ce}_{0.9} \mathrm{O}_{2-\delta}$ (GDC, Fuel Cell Materials) tape casting slurry was prepared following standard procedures. The raw tapes were heat-treated stepwise to a maximum temperature of $1450^{\circ} \mathrm{C}$ for $4 \mathrm{~h}$ to obtain a thick GDC support. GDC sintered tapes having thicknesses in the range of 140 $230 \mu \mathrm{m}$ were used in this study. Already prepared Zn-LBS and 20 wt $\%$ poly (methyl methaacrylate) $(10 \mu \mathrm{m}$, PMMA-Soken) pore former were mixed with commercial ink making vehicle (ESL ElectroScience, type 441) to make an ink of screen printing consistency. The half-cells were prepared by depositing Zn-LBS ink on the GDC electrolyte by doctor-blade coating. The resulting half-cells were sintered at $1200^{\circ} \mathrm{C}$ for $4 \mathrm{~h}$ to bond Zn-LBS $(\sim 60 \mu \mathrm{m})$ to the GDC substrate. The half-cell was then deposited with LSCF-GDC $(\sim 20 \mu \mathrm{m})$ cathode on the other side and sintered at $1100^{\circ} \mathrm{C}$ for $2 \mathrm{~h}$. The SOFC active area was $0.50 \mathrm{~cm}^{2}$ and gold wires and silver paste were used as leads and current collector on the anode and cathode. Catalytic activity for $\mathrm{H}_{2}$ oxidation and oxide-ion conductivity in the anode was introduced by
NiO-GDC infiltration. $0.75 \mathrm{M}$ of NiO-GDC $\left(\mathrm{Ce}_{0.9} \mathrm{Gd}_{0.1} \mathrm{O}_{2-\delta}\right)$ precursor was prepared by dissolving $\mathrm{Ni}\left(\mathrm{NO}_{3}\right)_{2} \cdot 6 \mathrm{H}_{2} \mathrm{O}, \mathrm{Ce}\left(\mathrm{NO}_{3}\right)_{3} \cdot 6 \mathrm{H}_{2} \mathrm{O}$, $\mathrm{Gd}\left(\mathrm{NO}_{3}\right)_{3} \cdot 6 \mathrm{H}_{2} \mathrm{O}$ in water. The NiO-GDC contains $10 \mathrm{wt} \%$ of $\mathrm{Ni}$ relative to GDC. Few drops of prepared solution were infiltrated into the porous $\mathrm{Zn}$-LBS scaffold and placed in the vaccum chamber for 5 minutes. Between each successive infiltration step, the sample was heat-treated at $450^{\circ} \mathrm{C}$ for an hour to decompose the nitrate salts. The loading of NiO-GDC was determined by measuring the weight gain after final heat-treatment step and compared to the initial weight of the sample. NiO-GDC loading after 9 infiltrations was estimated to be $5.30,3.34,3.84 \mathrm{wt} \%$ for $1 \%, 2 \%$ and $3 \% \mathrm{Zn}$-LBS samples, respectively. It is to be noted that the number of infiltrations was kept constant for all samples and as a result $1 \%$ Zn-LBS showed higher weight gain due the higher LBS layer porosity.

Current-voltage (I-V) characteristics and power density of the SOFCs was determined using a ParStat 2273/Solartron 1470E. The electrochemical impedance spectroscopy (EIS) response of the SOFCs under investigation were obtained using ParStat 2273/ Solartron 1425 frequency response analyzer. The SOFC was loaded in the fuel cell testing fixture to determine the electrochemical performance including I-V and impedance spectra. Commercial two-part sealant (ceramabond-517, Aremco) was used as seal between anode and cathode side. The anode and cathode side of the fixture was flown with $100 \mathrm{ml} / \mathrm{min}$ of humidified $\mathrm{H}_{2}$ and air, respectively. Impedance spectra were measured in 2-point probe method over a frequency ranges from $100 \mathrm{mHz}$ to $100 \mathrm{kHz}$ under open-circuit voltage (OCV) conditions. The impedance spectra were obtained for the full cell which includes the contribution from cathode, electrolyte and anode. The impedance spectra were fitted with an equivalent circuit model using the code ZsimpWin with a complex non-linear squares fitting routine (CNLS).

Scanning electron microscopy (SEM) of the post-tested SOFCs was performed using a Hitachi SU-70 with field emission gun equipped with a Bruker XFlash silicon drift EDS detector. Change in weight during solid-state synthesis was determined using thermogravimetric analysis (TGA) analytical instrument, TA SDT Q600. The sample was heated at a ramp rate of $5^{\circ} \mathrm{C} / \mathrm{min}$ to $1000^{\circ} \mathrm{C}$ in the presence of air flow $(100 \mathrm{ml} / \mathrm{min})$.

\section{Results and Discussion}

TGA of LBS precursor (a mixture of $\mathrm{BaCO}_{3} / \mathrm{SnO}_{2} / \mathrm{La}_{2} \mathrm{O}_{3}$ ) is shown in Figure 1a. TGA reveals an initial weight loss of $2.5 \%$ in the temperature ranges of $21-200^{\circ} \mathrm{C}$ attributed to the evaporation of $\mathrm{H}_{2} \mathrm{O}$ (region 1). At temperature $>200^{\circ} \mathrm{C}$ (region 2), the departure of residual $\mathrm{H}_{2} \mathrm{O}$ and sublimation of carbonates begins and the weight loss is gradual until $800^{\circ} \mathrm{C}$, beyond which, a rapid weight loss occurred implying a complete removal of carbonate and onset of $\mathrm{BaSnO}_{3}$ perovskite formation. No change in weight loss at temperature $>960^{\circ} \mathrm{C}$ was observed indicating formation of LBS single phase (region 3). Shown in Figure $1 \mathrm{~b}$ are the XRD pattern of LBS precursor at $25^{\circ} \mathrm{C}$ and calcined samples at 500 and $1000^{\circ} \mathrm{C}$. XRD pattern of LBS precursor calcined at $500^{\circ} \mathrm{C}$ showed $\mathrm{BaCO}_{3}$ reflection; however, the intensity of these reflections are less compared to XRD pattern of as-mixed powders at $25^{\circ} \mathrm{C}$ indicating a slight loss of carbonates. The XRD pattern of LBS powder calcined at $1000^{\circ} \mathrm{C}$ showed a cubic phase consistent with TGA measurements.

One of the main issues with LBS based ceramic oxides is their poor sintering characteristics. For example, $\mathrm{BaSnO}_{3}$ based perovskite oxide showed only a maximum density of $80 \%$ even at a high sintering temperature of $1600^{\circ} \mathrm{C}$. Y. Wang et al studied the effect of using $\mathrm{ZnO}$ as additive in $\mathrm{BaSn}_{0.75} \mathrm{Y}_{0.25} \mathrm{O}_{3}$ based proton-conducting ceramic oxide. ${ }^{17}$ Their investigation revealed that addition of $3.25 \mathrm{wt} \% \mathrm{ZnO}$ reduced the sintering temperature down to $1300^{\circ} \mathrm{C}$. Shown in Figure 2a are the XRD patterns of LBS with varying amount of $\mathrm{ZnO}$ additive from 0 to $3 \mathrm{wt} \%$. No appearance of secondary phases or segregation of $\mathrm{ZnO}$ occurred up to $3 \mathrm{wt} \%$ loading of $\mathrm{ZnO}$. Figure $2 \mathrm{~b}$ shows the lattice parameters of the Zn-LBS from $0-3$ wt \%. Although there is no chemical reaction between $\mathrm{ZnO}$ and LBS, the lattice parameter shrunk slightly due to addition of $\mathrm{ZnO}$ indicating the possibility of 

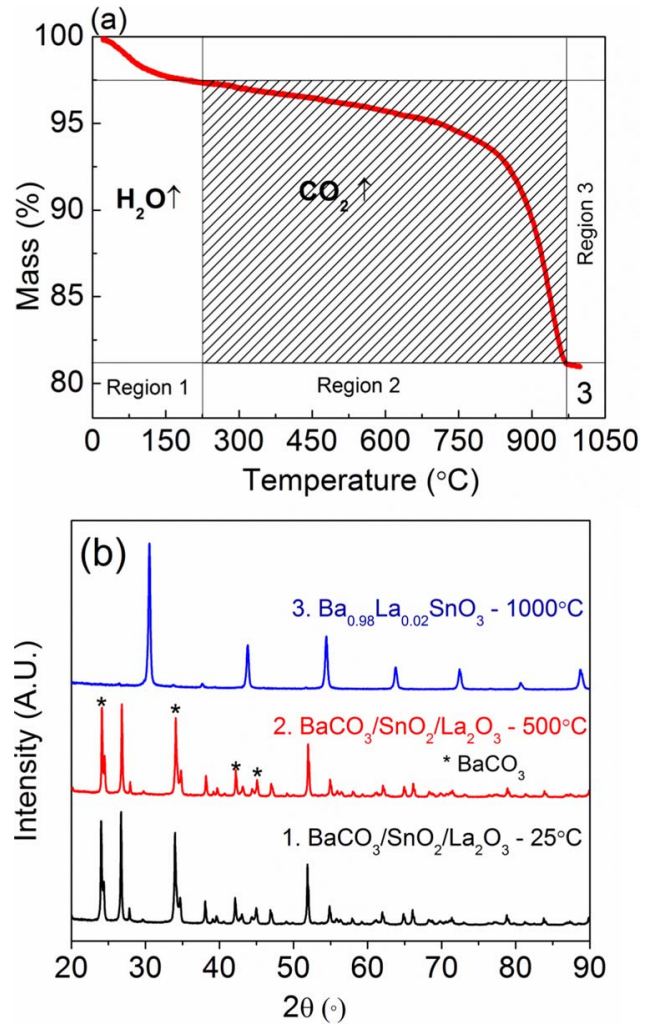

Figure 1. (a) Thermogravimetric analysis of $\mathrm{BaCO}_{3} / \mathrm{SnO}_{2} / \mathrm{La}_{2} \mathrm{O}_{3}$ mixture in air and (b) XRD patterns of the $\mathrm{BaCO}_{3} / \mathrm{SnO}_{2} / \mathrm{La}_{2} \mathrm{O}_{3}$ mixture at 25,500 and $1000^{\circ} \mathrm{C}$ in air.

$\mathrm{ZnO}$ dissolution in the lattice of LBS. However, the difference in lattice parameter of pristine LBS (4.116 $)$ is comparable to $3 \mathrm{wt} \%$. $\mathrm{ZnO}$ doped sample $(4.115 \AA)$ when considering the experimental error. Further, the crystallite size extracted from XRD data increased from $168 \mathrm{~nm}$ to $400 \mathrm{~nm}$ with $3 \mathrm{wt} . \% \mathrm{ZnO}$ addition. Shown in Figure $2 \mathrm{c}$ is the shrinkage behavior of pristine and Zn-LBS ceramic oxide measured using the geometrical changes. A $\sim 15 \%$ shrinkage is obtained for all $\mathrm{ZnO}$ concentrations investigated. These results convincingly illustrate that even 1wt. \% of $\mathrm{ZnO}$ acts as a sintering aid for LBS.

One of the main requirements of alternative anode development is high electrical conductivity. Most of the ceramic oxides, when prereduced at a low temperature of $650^{\circ} \mathrm{C}$ have shown low electrical conductivity. For instance, an in-house measurement of $\mathrm{SrTi}_{0.75} \mathrm{Nb}_{0.25} \mathrm{O}_{3}$ ceramic oxide showed a low conductivity of $1.8 \mathrm{~S} / \mathrm{cm}$ at $650^{\circ} \mathrm{C}$ in $10 \% \mathrm{H}_{2} / \mathrm{N}_{2}$. However, an electrical conductivity of $>10 \mathrm{~S} / \mathrm{cm}$ is required to obtain efficient LT-SOFCs. Figure 3 shows the electrical conductivity of LBS with and without the addition of $\mathrm{ZnO}$ measured in $10 \% \mathrm{H}_{2} / 3 \mathrm{H}_{2} \mathrm{O} / \mathrm{N}_{2}$. Base LBS without $\mathrm{ZnO}$ doping showed a comparatively low conductivity of $23 \mathrm{~S} / \mathrm{cm}$ at $650^{\circ} \mathrm{C}$, mainly due to its high porosity $(\sim 50.4 \%)$ and poor shrinkage behavior. However, samples with gradual addition of $\mathrm{ZnO}$ from 1 to $3 \mathrm{wt} \%$ show a dramatic enhancement in conductivity. The conductivity of the samples is in the order $3 \mathrm{wt} \%(210 \mathrm{~S} / \mathrm{cm})>2 \mathrm{wt} \%(123 \mathrm{~S} / \mathrm{cm})>1 \mathrm{wt} \%(78 \mathrm{~S} / \mathrm{cm})$ at $650^{\circ} \mathrm{C}$ and the trend follows at all temperatures. The conductivity of the samples depends on the porosity i.e., the denser sample the better the conductivity. In addition, the enhanced conductivity in all Zn-LBS samples compared to the pristine LBS could be due to the enrichment of $\mathrm{Zn}$ at the grain boundaries. It is expected that the un-reacted $\mathrm{ZnO}$ sublimed due to high sintering temperature. The conductivity values at lower temperatures are higher than $650^{\circ} \mathrm{C}$ due to metallic-type conduction behavior of Zn-LBS.

Anode materials must withstand redox cycles due to fuel starvation conditions during practical operation of SOFC stacks. Redox stability was determined by alternating between $10 \% \mathrm{H}_{2} / 3 \% \mathrm{H}_{2} \mathrm{O} / \mathrm{N}_{2}$ and air at
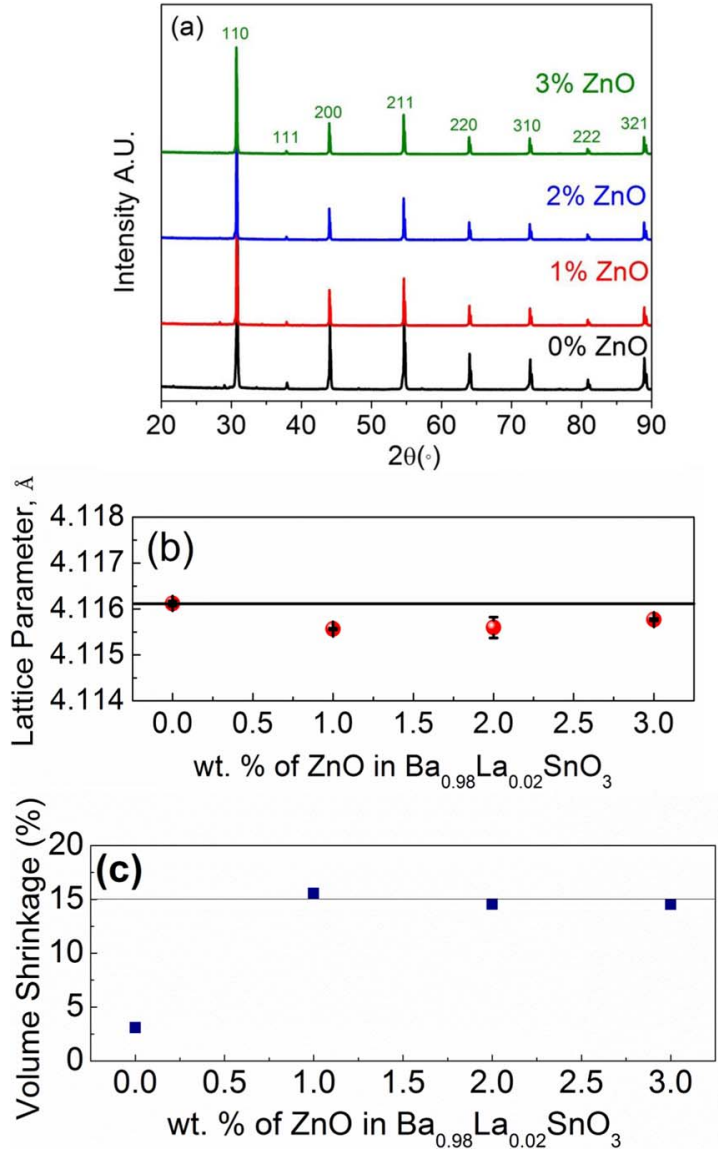

Figure 2. (a) XRD patterns of LBS with $0,1,2$ and $3 \mathrm{wt} \% \mathrm{ZnO}$. (b) Lattice parameters of LBS with $0,1,2$ and $3 \mathrm{wt} \% \mathrm{ZnO}$ additions. (c) Volumetric shrinkage of LBS with the addition of $0,1,2$ and $3 \mathrm{wt} \% \mathrm{ZnO}$ sintered at $1550^{\circ} \mathrm{C}$ for $6 \mathrm{~h}$.

$650^{\circ} \mathrm{C}$ over a period of $200 \mathrm{~h}$ with a $3 \mathrm{wt} \% \mathrm{Zn}$-LBS sample as shown in Figure 4a. No change in conductivity at each gas composition was observed up to 10 redox cycles indicating an excellent redox stability of LBS anode. The conductivity value at $650^{\circ} \mathrm{C}$ under reducing gases is higher than the value reported in Figure 3, because the sample was left in reducing conditions for about $450 \mathrm{~h}$ before the redox cycling experiment.

In addition, the anode support should not propagate cracks that lead to mechanical failure during heating/cooling cycles. Thermal stability

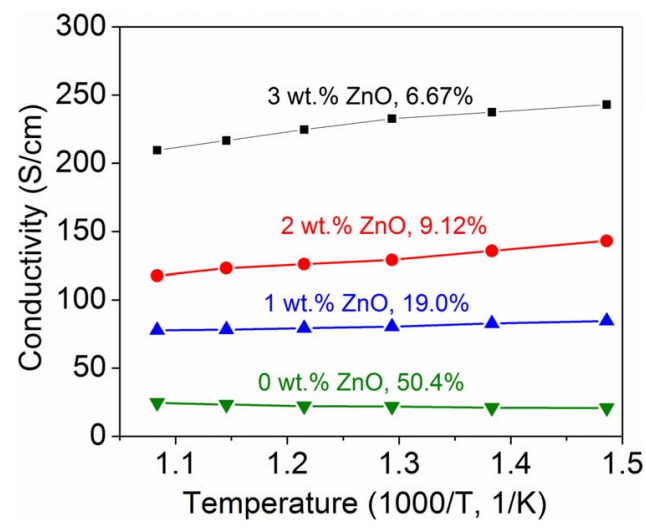

Figure 3. DC electrical conductivity measurement of LBS with $0,1,2$ and $3 \mathrm{wt} \% \mathrm{ZnO}$ sintered at $1550^{\circ} \mathrm{C}$ for $6 \mathrm{~h}$ and the measurements were made in $10 \% \mathrm{H}_{2} / \mathrm{N}_{2} / 3 \% \mathrm{H}_{2} \mathrm{O}$. 

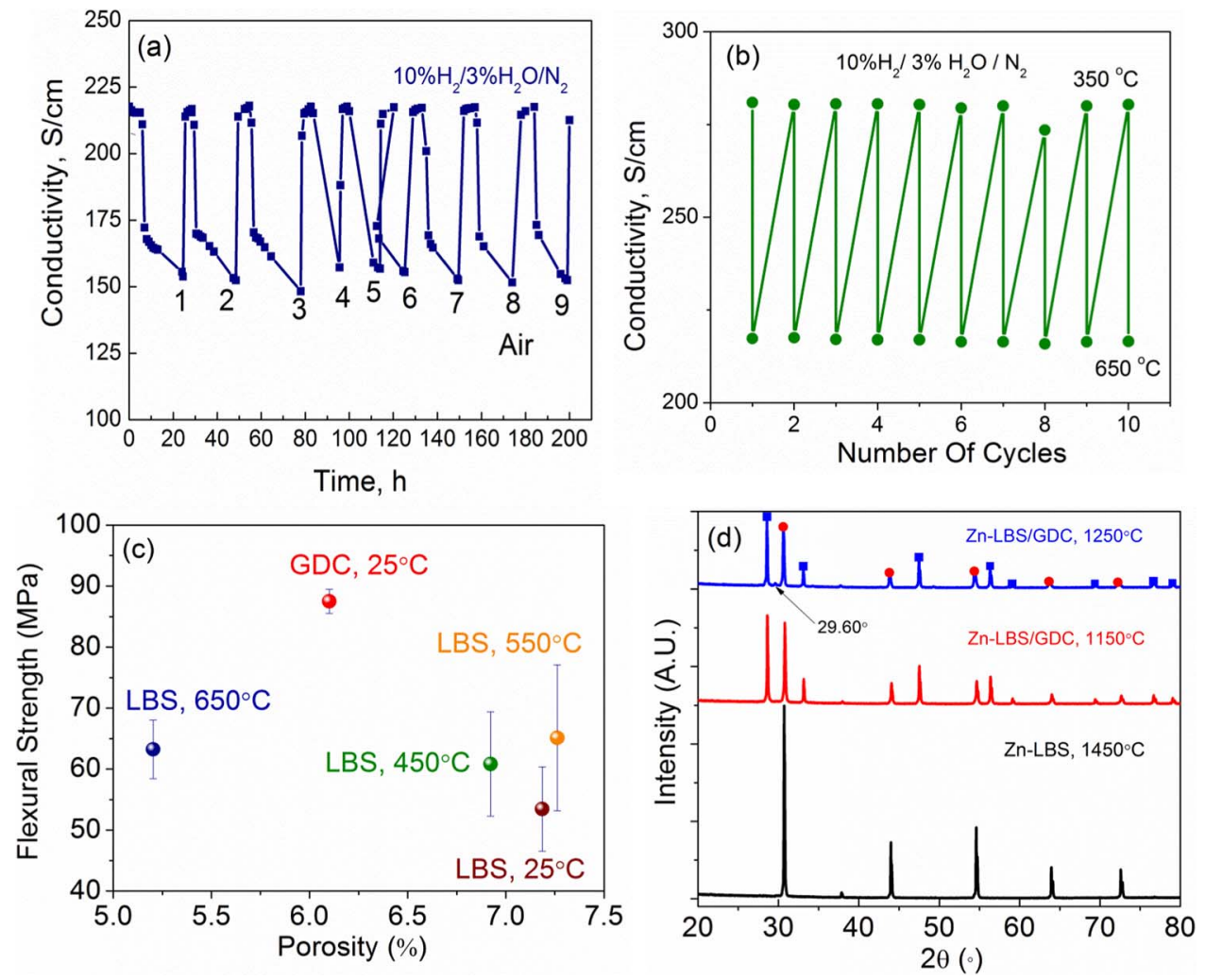

Figure 4. (a) Redox stability of 3 wt $\%$ Zn-LBS. (b) Thermal stability of 3 wt $\%$ Zn-LBS cycled between 350 and $650^{\circ} \mathrm{C}$, (c) Flexural strength of 3 wt $\%$ Zn-LBS samples as a function of porosity in the ranges between 5.2-7.3\% at different temperatures and (d) XRD patterns of LBS/GDC composite. The solid squares are GDC and solid circles represent 3 wt $\%$ Zn-LBS peaks.

was determined in reducing gas conditions by cycling the sample between 650 and $350^{\circ} \mathrm{C}$ for 10 cycles at a high ramp rate of $10^{\circ} \mathrm{C} / \mathrm{min}$ as shown in Figure $4 \mathrm{~b}$. The investigation revealed that $3 \mathrm{wt} \% \mathrm{Zn}$ LBS retained its conductivity $\left(216\right.$ and $280 \mathrm{~S} / \mathrm{m}$ at 650 and $350^{\circ} \mathrm{C}$, respectively) after several heating/cooling cycles demonstrating good thermal stability and indicating no crack formation during cycling.

The anodes are the principle structural component in an anodesupported SOFC and must have sufficient mechanical strength. ZnLBS samples were used to determine the flexural strength using a three point bend test and results are shown in Figure 4c. Tests were carried out at room temperature and various elevated temperatures $\left(450,550\right.$ and $\left.650^{\circ} \mathrm{C}\right) .3 \mathrm{wt} \% \mathrm{Zn}$-LBS showed very little variation in strength across the $5.2-7.3 \%$ porosity range. The variation in porosity $(\sim 2 \%)$ between samples arises due to the temperature gradient in the furnace. Samples tested at elevated temperatures were more resilient to fracture than those tested at room temperature. For example, a flexural strength of $\sim 66 \mathrm{MPa}$ was obtained at $550^{\circ} \mathrm{C}$ as compared to $\sim 54 \mathrm{MPa}$ at room temperature for $3 \mathrm{wt} . \% \mathrm{Zn}$-LBS having the same porosity of $\sim 7.3 \%$.

Flexural strength of Zn-LBS is $29 \%$ lower than GDC ( $\sim 87 \mathrm{MPa})$ at $25^{\circ} \mathrm{C}$ as shown in Figure $4 \mathrm{c}$. However, it must be noted that under reducing gas conditions ceria undergoes crystal lattice expansion leading to poor mechanical properties. ${ }^{26}$

Lack of reactivity between GDC and Zn-LBS is essential to fabricate a successful SOFC. Figure $4 d$ shows the XRD patterns for LBS, GDC, and 3wt. \% Zn-LBS/GDC composite sintered at 1150 to $1250^{\circ} \mathrm{C}$. No formation of secondary phase is seen for the sample fired at $1150^{\circ} \mathrm{C}$, however, secondary phase starts to appear $(2 \theta=29.60)$ for the sample fired at $1250^{\circ} \mathrm{C}$ for $6 \mathrm{~h}$, which could put an upper limit on electrolyte sintering temperature.

The electrode/electrolyte interface and the microstructure of the $\mathrm{Zn}$-LBS anodes were examined. Figures $5 \mathrm{a}-5 \mathrm{i}$ shows SEM micrographs of post-tested $1 \%, 2 \%$, and $3 \mathrm{wt} \% \mathrm{Zn}-\mathrm{LBS} / \mathrm{GDC}$ based
SOFCs. Figures 5a, 5d, and 5g illustrates the cross section of electrode/electrolyte interfaces for 1, 2, and $3 \mathrm{wt} \% \mathrm{Zn}$-LBS samples, respectively. As seen from the images, GDC electrolytes are fully dense and well-bonded with the LBS electrodes. The micrographs of the LBS anodes with higher magnifications are shown in Figures $5 b$, $5 \mathrm{e}$, and $5 \mathrm{~h}$. The images show that $1 \mathrm{wt} \% \mathrm{Zn}$-LBS has higher porosity and finer microstructure (c.f. Figure 5b) than 2 and $3 \mathrm{wt} \% \mathrm{Zn}$-doped LBS that are shown in Figures $5 \mathrm{e}$ and $5 \mathrm{~h}$, respectively.

SOFC performance can be improved by the decoration of electron conducting scaffold with nanoparticles of $\mathrm{Ni}$ and GDC, wherein, $\mathrm{Ni}$ assists $\mathrm{H}_{2}$ oxidation and GDC facilitates the extension of triple phase boundaries. ${ }^{13-15}$ The images in Figures 5c, 5f and 5i revealed the nano-morphology of Ni-GDC that was infiltrated into the porous LBS scaffolds. Ni-GDC particles finely decorated on the surface of LBS. The elements were confirmed using EDS analysis.

EDS line scan analysis was performed at the interface of the porous Zn-LBS anode and the GDC electrolyte as shown in Figure 6. The elemental distribution across the interface of Zn-LBS/GDC was collected over a $35 \mu \mathrm{m}$ length. The anode region shows the high intensity of $\mathrm{Ba}$ and $\mathrm{Sn}$. The appearance of $\mathrm{Ce}$ signal in anode region is due to the Ni-GDC that was infiltrated on the surface of Zn-LBS. Further, it is to be noted that the intensity of $\mathrm{Zn}, \mathrm{Ni}$ and $\mathrm{La}$ are significantly less because of their lower quantities in the anode region. In the GDC electrolyte region; the intensity of $\mathrm{Ce}$ and $\mathrm{Gd}$ were much higher compared to rest of the elements. EDS analysis has the detection limit of $<1 \%$, thus further investigation is required for accurate quantification of elemental crossover between electrode and electrolyte.

Preliminary fuel cell performance in humidified $\mathrm{H}_{2}$ as fuel and air as oxidant was obtained with Zn-LBS anodes on GDC based electrolyte-supported SOFCs. Electrolyte-supported cells were used because they were easier to make with the new anode material as compared to anode-supported cells. Typical I-V and power density plots at 550,600 and $650^{\circ} \mathrm{C}$, for $1 \%, 2 \%$, and $3 \% \mathrm{Zn}-\mathrm{LBS}$ are shown in 


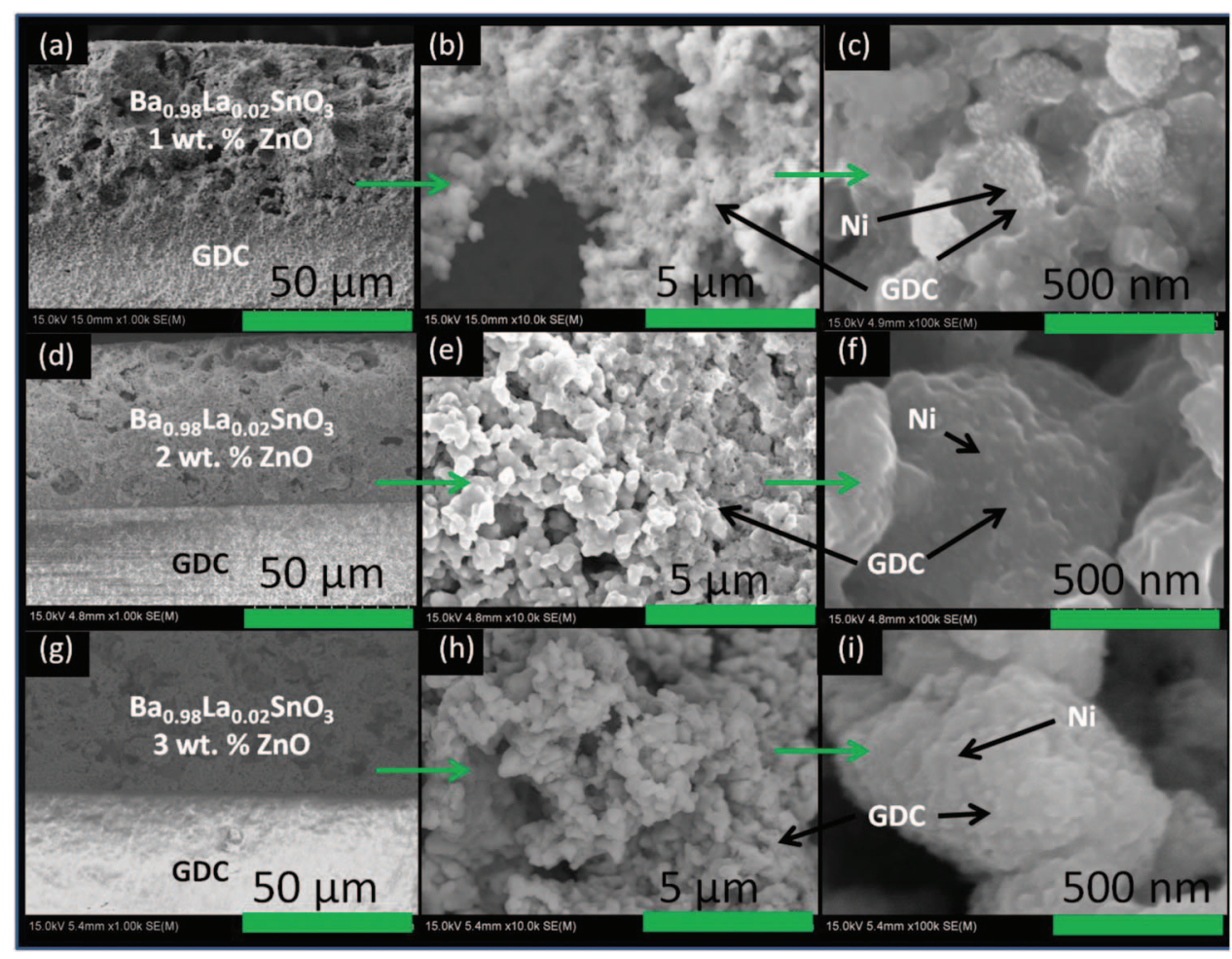

Figure 5. (a-i) is the SEM images of post-tested LBS based electrolyte-supported SOFCs. (a) electrode/electrolyte cross section of 1 wt\% Zn-LBS. (b) Morphology of $1 \mathrm{wt} \% \mathrm{Zn}$-LBS scaffold. (c) Decoration of Ni-GDC nanoparticles on the surface of $1 \mathrm{wt} \% \mathrm{Zn}$-LBS scaffold. (d) electrode/electrolyte cross section of 2 wt $\%$ Zn-LBS. (e) Morphology of 2 wt\% Zn-LBS scaffold. (f) Decoration of Ni-GDC nanoparticles on the surface of 2 wt\% Zn-LBS scaffold. (g) electrode/electrolyte cross section of $3 \mathrm{wt} \% \mathrm{Zn}$-LBS. (h) Decoration of Ni-GDC nanoparticles on the surface of $3 \mathrm{wt} \% \mathrm{Zn}$-LBS scaffold and (i) Decoration of Ni-GDC nanoparticles on the surface of $3 \mathrm{wt} \% \mathrm{Zn}-\mathrm{LBS}$ scaffold.

Figures $7 \mathrm{a}, 7 \mathrm{~b}$, and $7 \mathrm{c}$, respectively. In Figures $7 \mathrm{a}-7 \mathrm{c}$, the area specific resistance (ASR) decreases with increase in temperature due to faster electrode kinetics and higher oxide-ion conductivity. However, the open circuit value $(\mathrm{OCV})$ decreases with increasing temperature due to the increase in electronic transference number of GDC. Highest power densities of $0.28 \mathrm{~W} / \mathrm{cm}^{2}$ (at $0.6 \mathrm{~A} / \mathrm{cm}^{2}, \mathrm{OCV}: 0.89 \mathrm{~V}$ ) and 0.17 $\mathrm{W} / \mathrm{cm}^{2}$ (at $0.36 \mathrm{~A} / \mathrm{cm}^{2}, \mathrm{OCV}: 0.93 \mathrm{~V}$ ) were achieved at 650 and $600^{\circ} \mathrm{C}$, respectively for $2 \mathrm{wt} \% \mathrm{Zn}-\mathrm{LBS}$ (shown in Figure 7b). The ASR of $1 \% \mathrm{Zn}-\mathrm{LBS}$ is higher than $2 \% \mathrm{Zn}-\mathrm{LBS}$, and the ASR of $2 \% \mathrm{Zn}-\mathrm{LBS}$ is comparable to $3 \% \mathrm{Zn}-\mathrm{LBS}$. These arise from the GDC thickness

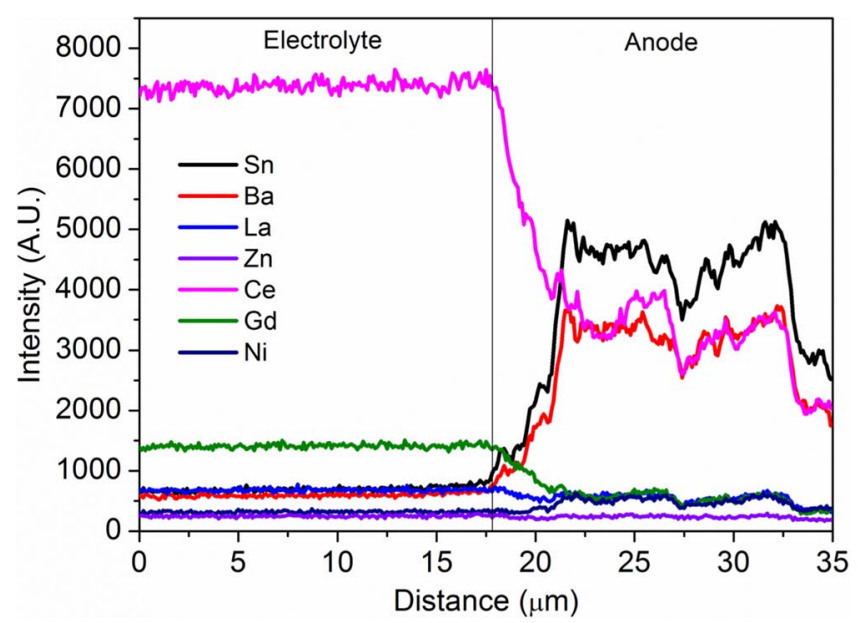

Figure 6. EDS analysis of $3 \mathrm{wt} . \% \mathrm{Zn}-\mathrm{LBS}$ deposited on GDC which was fired at $1200^{\circ} \mathrm{C}$ for $6 \mathrm{~h}$ in air. variation between samples. GDC thickness of 230, 140 and $150 \mu \mathrm{m}$ were used for $1 \% \mathrm{Zn}$-LBS, $2 \% \mathrm{Zn}-\mathrm{LBS}$ and $3 \% \mathrm{Zn}-\mathrm{LBS}$, respectively.

Figures $8 \mathrm{a}-8 \mathrm{c}$ are the EIS measurements of 1,2 and $3 \mathrm{wt} \% \mathrm{Zn}$ LBS at 650,600 and $550^{\circ} \mathrm{C}$. The impedance spectra were measured on the electrolyte supported full cells infiltrated with Ni-GDC on the anode side. The impedance spectra in all samples showed similar features. An equivalent circuit $\left\{\mathrm{LR}_{0}\left(\mathrm{R}_{1} \mathrm{Q}_{1}\right)\left(\mathrm{R}_{2} \mathrm{Q}_{2}\right)\right\}$, containing inductance $(\mathrm{L})$, the electrolyte series resistance, $\mathrm{R}_{0}$ in series with elements $\left(\mathrm{R}_{1} \mathrm{Q}_{1}\right)$ and $\left(\mathrm{R}_{2} \mathrm{Q}_{2}\right)$ was used to model the spectra. $\mathrm{R}_{1}$ and $\mathrm{Q}_{1}$ were parallel to each other and the same applies to $R_{2}$ and $Q_{2}$. The constant phase elements $\mathrm{Q}_{1}$ and $\mathrm{Q}_{2}$ were used in the place of pure capacitor considering the distributed catalytic activity of the porous microstructure. The impedance value of $\mathrm{Q}_{1}\left(=\mathrm{Q}_{2}\right)$ is given by the relation $1 / Y_{0} n(j \omega)$, where, $Y_{0}$ is the a constant, $\omega$ is the angular frequency and $\mathrm{n}$ is the frequency power. The inductive component at very high frequencies arises from the measurement leads and is not shown in the plots. It is impossible to distinguish the anode and cathode ASR without reference electrode. Further, the time constants occurring in various electrode processes are overlapped in the spectra. A high frequency $\operatorname{arc}\left(\mathrm{R}_{1}\right)$ is attributed to the cathode and anode charge transfer polarizations caused by the transportation of charged species at the interfaces of electrodes/electrolyte. The species include electrons, oxide ions and potentially protons in the anode. A low frequency arc $\left(R_{2}\right)$ is attributed to the mass transfer limitation in electrodes caused by diffusion of adsorbed species on the surface of electrodes and gas diffusion limitations. In particular, the inductive loops (in the positive axis) at the very low frequencies originate from the coupling of mass transfer and surface reactions (e.g. absorption of moisture on anode surface). The inductive loops were removed during the fitting procedure for simplification.

The ohmic ASR of the electrode and electrolytes for SOFCs under investigation were subtracted from the impedance spectra and are shown in Figure 8 d. At $650^{\circ} \mathrm{C}$, the ohmic ASR of $0.43,0.35$ and 

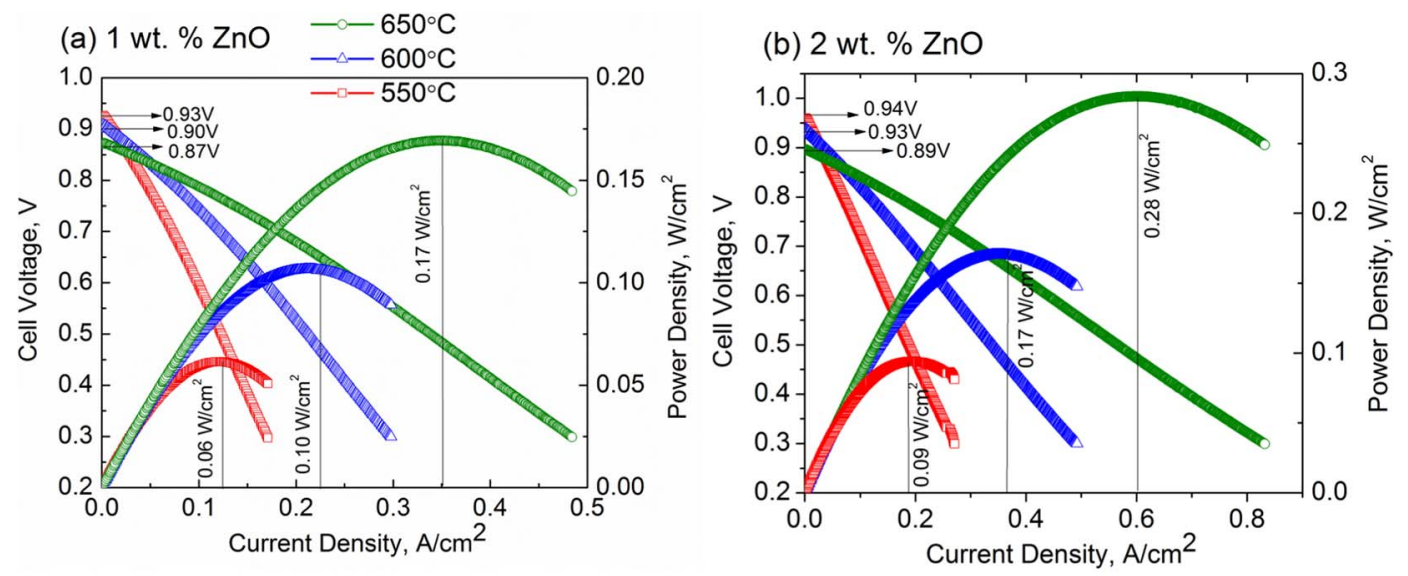

(c) 3 wt. \% $\mathrm{ZnO}$

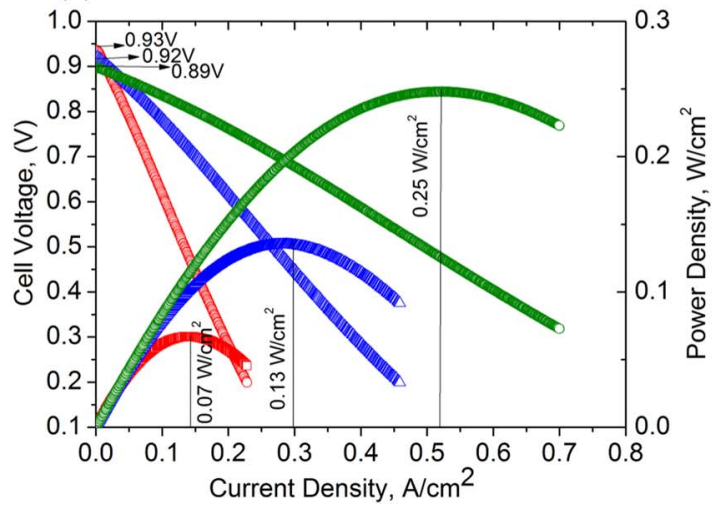

Figure 7. I-V and power density characterizations on GDC based electrolyte-supported cells. (a) $1 \mathrm{wt} \% \mathrm{Zn}$-LBS infiltrated with Ni-GDC loading of 5.3 wt\% (b) $2 \mathrm{wt} \% \mathrm{Zn}-\mathrm{LBS}$ infiltrated with Ni-GDC loading of $3.34 \mathrm{wt} \%$ and (c) $3 \mathrm{wt} \% \mathrm{Zn}$-LBS infiltrated with Ni-GDC loading of 3.84\%. The amount of Ni-GDC loading varies depending on the porosity of the anodes.

$0.65 \Omega \mathrm{cm}^{2}$ was obtained for 1,2 and $3 \mathrm{wt} \% \mathrm{Zn}-\mathrm{LBS}$. Variation in ohmic ASR between the samples are mainly from the GDC thicknesses. The calculated ohmic ASR of $230 \mu$ m-thick-GDC is $0.85 \Omega$ $\mathrm{cm}^{2}$ at $650^{\circ} \mathrm{C}$ corresponding to its bulk conductivity of $0.027 \mathrm{~S} / \mathrm{cm}$ at $650^{\circ} \mathrm{C}$ measured in air. ${ }^{27}$ However, the experimentally obtained ohmic ASR is $\sim 23 \%$ lower than the calculated value. A similar ohmic behavior can be deduced from the data reported by B.D. Madsen et al. for a $\sim 300 \mu \mathrm{m}$ GDC based electrolyte-supported SOFC with $\mathrm{La}_{0.8} \mathrm{Sr}_{0.2} \mathrm{Cr}_{0.98} \mathrm{~V}_{0.02} \mathrm{O}_{3-\delta}$ as anode and LSCF-GDC cathode. ${ }^{28}$ The experimental ohmic ASR was $\sim 10 \%$ lower than the calculated value. As such, this can be attributed to the reduction of $\mathrm{Ce}^{4+}$ to $\mathrm{Ce}^{3+}$ over the anode portion of the electrolyte that had been exposed to reducing gas conditions. Secondly, the grain boundary resistance of GDC electrolyte could overlap with the non-ohmic ASR; however, respective time constants are difficult to resolve at temperature $>500^{\circ} \mathrm{C} .{ }^{27}$ Further, diffusion of elements from the electrode could decrease the ohmic ASR; however they have no detrimental effects on the OCV in our study. The ohmic ASR contribution of electrodes is much lower $\left(<0.00003 \Omega \mathrm{cm}^{2}\right)$ considering their thickness and high conductivity.

Non-ohmic ASR $\left(\mathrm{R}_{1}+\mathrm{R}_{2}\right)$ i.e., charge-transfer and concentration polarization measured at different temperatures are shown in Figure 8e. $1 \mathrm{wt} \% \mathrm{Zn}$-LBS showed lowest non-ohmic ASR of $0.16 \Omega \mathrm{cm}^{2}$, while 2 and $3 \mathrm{wt} \%$ showed 0.18 and $0.19 \Omega \mathrm{cm}^{2}$, respectively at $650^{\circ} \mathrm{C}$, and this trend continues down to $550^{\circ} \mathrm{C}$. In a previous study reported by Hussain et al, a non-ohmic ASR of $0.21 \Omega \mathrm{cm}^{2}$ at $650^{\circ} \mathrm{C}$ was obtained on $\mathrm{Nb}$-doped $\mathrm{SrTiO}_{3}$ ceramic anode infiltrated with $\mathrm{Ni}$ GDC. ${ }^{13-15}$ This value was determined using symmetrical cell made of $\mathrm{Nb}$-doped $\mathrm{SrTiO}_{3}$ scaffold deposited on either side of YSZ. In the present study the total non-ohmic ASR for $3 \mathrm{wt} \% \mathrm{Zn}-\mathrm{LBS}(0.19 \Omega$ $\mathrm{cm}^{2}$ ) is comparatively low considering the contribution from anode and cathode altogether. Further, the variation in non-ohmic ASR between the samples in the present study depends on the loading of $\mathrm{Ni}-\mathrm{GDC}$. The higher the Ni-GDC loading the lower is the non-ohmic ASR, i.e., the loading of Ni-GDC was in the order $1 \mathrm{wt} \%>2 \mathrm{wt} \%$ $>3$ wt. \% Zn-LBS. The number of infiltrations of Ni-GDC was fixed and the amount of loading obtained increased based on anode porosity and microstructure. Additionally, under low $\mathrm{PO}_{2}$ in the temperature range $400-650^{\circ} \mathrm{C}$, LBS is a mixed electronic and proton-conducting ceramic oxide. ${ }^{29}$ However, non-ohmic ASR of pristine $3 \mathrm{wt} \% \mathrm{Zn}$-LBS tested using electrolyte-supported SOFC showed high values of 6.34, 11.51 and $35.93 \Omega \mathrm{cm}^{2}$ at 650,600 and $550^{\circ} \mathrm{C}$, respectively, measured under humidified $\mathrm{H}_{2}$. These high values indicate that pristine LBS can only be an electronic conducting scaffold similar to that of $\mathrm{Nb}$-doped $\mathrm{SrTiO}_{3}{ }^{13-15}$ and has insufficient catalytic activity and oxide ion conductivity to function as stand-alone anode material. Furthermore, with regard to electronic conduction it should be noted that $\mathrm{SnO}_{2}$ is readily reduced to the metallic state in the presence of reducing gasses such as $\mathrm{H}_{2}$ under SOFC operating conditions which would reduce the ohmic ASR. However, the reducibility of LBS is expected to be less due to the stabilizing effect of the perovskite structure.

\section{Conclusions}

Electrical and physio-chemical properties of $\mathrm{Ba}_{0.98} \mathrm{La}_{0.02} \mathrm{SnO}_{3}$ were investigated considering the applicability of this material as a fuel electrode in LT-SOFCs. The addition of $\mathrm{ZnO}$ as sintering aid greatly improved the sinterability and the electrical properties of LBS. $3 \mathrm{wt} \% \mathrm{Zn}-\mathrm{LBS}$ showed a high conductivity of 216 and $280 \mathrm{~S} / \mathrm{cm}$ at 650 and $350^{\circ} \mathrm{C}$, respectively in $\mathrm{H}_{2}$-containing gas. Zn-LBS has shown excellent redox and thermal stability appropriate for LT-SOFCs. The 

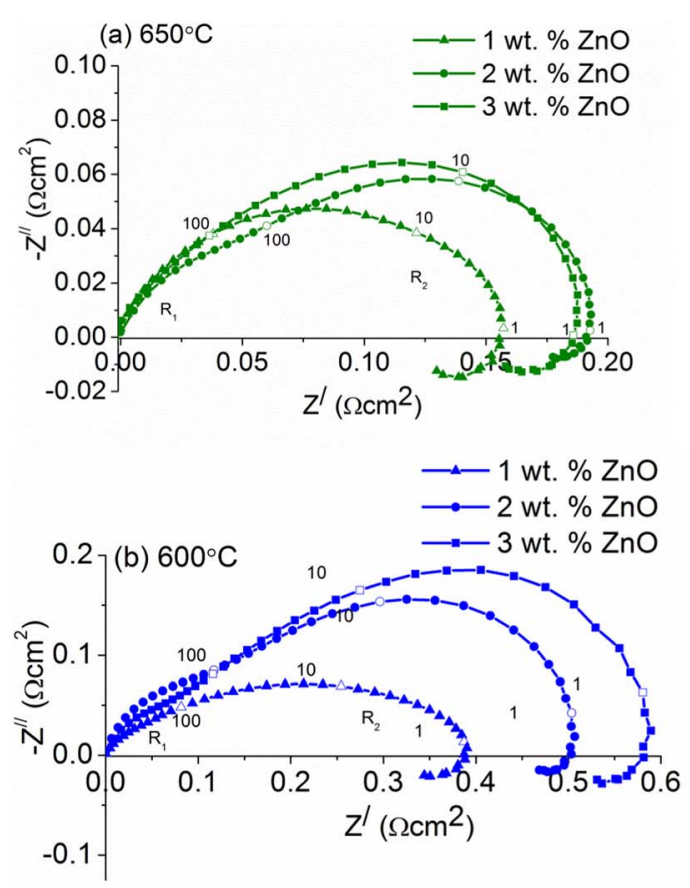

(c) $550^{\circ} \mathrm{C}$

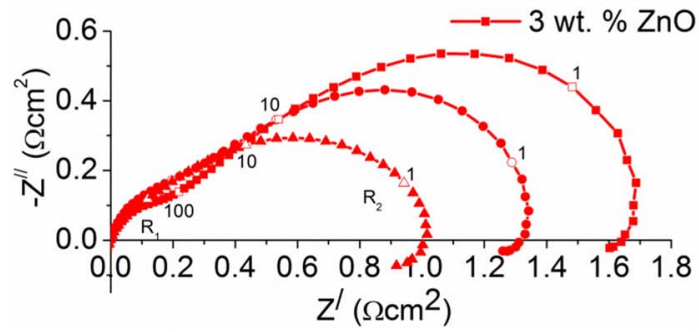

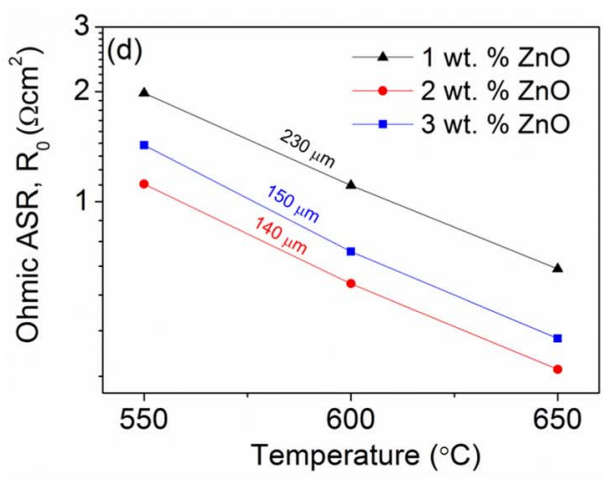

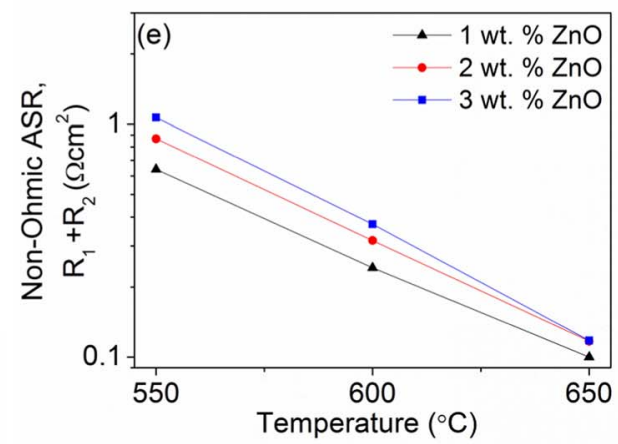

Figure 8. Impedance spectra measured for $1-3 \mathrm{wt} \%$ of Zn-LBS measured at (a) $650^{\circ} \mathrm{C}$, (b) $600^{\circ} \mathrm{C}$, (c) $550^{\circ} \mathrm{C}$, (d) Ohmic ASR Vs. temperature for the three concentrations of Zn-LBS and (e) Non-ohmic ASR vs. temperature for the three concentrations of Zn-LBS.

flexural strength at $550^{\circ} \mathrm{C}$ was higher than the room temperature measured value of $54 \mathrm{MPa}$. The fuel cell prepared using Zn-LBS (with $\mathrm{Ni}-$ GDC infiltration) as an anode and LSCF-GDC as a cathode has shown a peak power density of $280 \mathrm{~mW} / \mathrm{cm}^{2}$ at $650^{\circ} \mathrm{C}$ in $\mathrm{H}_{2}$ as fuel and air as the oxidant. The SOFC performance was limited by ohmic ASR arising from the thick electrolyte. The non-ohmic electrodes/electrolyte interfacial resistance of $1 \mathrm{wt} . \% \mathrm{Zn}-\mathrm{LBS}$ was lower than the 2 and $3 \mathrm{wt} \%$ due to a higher loading of Ni-GDC resulting from finer microstructure and higher porosity. Our study also indicates that pristine $\mathrm{Zn}$-LBS cannot be a stand-alone ceramic anode material and can function only as an electron conducting scaffold similar to that $\mathrm{Nb}$-doped $\mathrm{SrTiO}_{3}$ reported in literature.

\section{Acknowledgments}

This work was supported by DOE ARPA-E (DE-AR0000494) as a sub-contract through Redox Power Systems, LLC. Authors wish to Xizheng Wang for TGA measurements.

\section{References}

1. K. T. Lee, H. S. Yoon, and E. D. Wachsman, J. Mater. Res., 27, 16 (2012).

2. E. D. Wachsman, C. A. Marlowe, and K. T. Lee, Energy \& Environmental Science., 5, 2 (2012).

3. E. D. Wachsman and K. T. Lee, Science., 334, 6058 (2011).

4. D. J. Brett, A. Atkinson, N. P. Brandon, and S. J. Skinner, Chem. Soc. Rev., 37, 8 (2008).
5. T. W. Kueper and I. D. Bloom, international conference on heat resistant materials, Gatlingburg, TN (United States), link: http://www.osti.gov/scitech/ biblio/192466 (1995).

6. J. Malzbender, E. Wessel, and R. W. Steinbrech, Solid State Ionics., 176, 29 (2005).

7. L. Zhang, S. P. Jiang, H. Q. He, X. Chen, J. Ma, and X. C. Song, Int J Hydrogen Energy., 35, 22 (2010).

8. S. Tao and J. T. Irvine, Chemistry of materials., 16, 21 (2004).

9. S. Tao and J. T. Irvine, Nature materials., 2, 5 (2003).

10. S. Tao, J. T. Irvine, and S. M. Plint, The Journal of Physical Chemistry B., 110, 43 (2006).

11. Y. Huang, G. Liang, M. Croft, M. Lehtimaki, M. Karppinen, and J. B. Goodenough, Chemistry of Materials., 21, 11 (2009).

12. Y. H. Huang, R. I. Dass, Z. L. Xing, and J. B. Goodenough, Science., 312, 5771 (2006).

13. P. Blennow, K. K. Hansen, L. Reine Wallenberg, and M. Mogensen, Electrochim. Acta., 52, 4 (2006)

14. A. M. Hussain, J. V. Høgh, W. Zhang, and N. Bonanos, J. Power Sources., 216 (2012).

15. A. M. Hussain, J. V. Høgh, T. Jacobsen, and N. Bonanos, Int J Hydrogen Energy, 37, 5 (2012).

16. Y. Wang, E. Bevillon, A. Chesnaud, G. Geneste, and G. Dezanneau, The Journal of Physical Chemistry C., 113, 47 (2009).

17. Y. Wang, A. Chesnaud, E. Bevillon, J. Yang, and G. Dezanneau, Materials Science and Engineering: B., 176, 15 (2011).

18. P. H. Borse, U. A. Joshi, S. M. Ji, J. S. Jang, J. S. Lee, E. D. Jeong, and H. G. Kim, Appl. Phys. Lett., 90, 3 (2007).

19. M. Yasukawa, T. Kono, K. Ueda, H. Yanagi, and H. Hosono, Materials Science and Engineering: B., 173, 1 (2010).

20. T. Ishihara, K. Kometani, Y. Mizuhara, and Y. Takita, J. Electrochem. Soc., 139, 10 (1992).

21. S. Manorama and V. Rao, J. Mater. Sci.: Mater. Electron., 12, 2 (2001).

22. B. Hadjarab, A. Bouguelia, A. Benchettara, and M. Trari, J. Alloys Compounds., 461, 1 (2008). 
23. R. t. Shannon, Acta Crystallographica Section A: Crystal Physics, Diffraction, Theoretical and General Crystallography., 32, 5 (1976).

24. A. González-Angeles, G. Mendoza-Suarez, A. Gruskova, R. Dosoudil, and R. Ortega-Zempoalteca, Mater Lett., 58, 22 (2004).

25. B. Hadjarab, A. Bouguelia, and M. Trari, J. Phys. D., 40, 19 (2007).
26. A. Tomita, S. Teranishi, M. Nagao, T. Hibino, and M. Sano, J. Electrochem. Soc., 153, 6 (2006).

27. K. R. Reddy and K. Karan, Journal of Electroceramics., 15, 1 (2005).

28. B. D. Madsen and S. A. Barnett, Solid State Ionics., 176, 35 (2005).

29. S. Upadhyay and P. Kavitha, Mater Lett., 61, 8 (2007). 